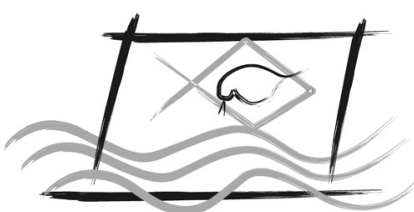

ECOTOX - BRASIL

\title{
Determination of genotoxic effect of trifluralin on Colossoma macropomum (Teleostei: Characidae: Serrasalminae, Cuvier, 1816) using a multibiomarker approach
}

\author{
Silva, J.M. ${ }^{1}$; Santos, F.L.B. ${ }^{1}$; Santos, R.V..; Barreto, E.O. ${ }^{2}$; Santos, E.L. ${ }^{3}$; Goulart Santana, A.E. ${ }^{1}$; \\ Rodarte, R.S. ${ }^{2}$; Machado, S.S. ${ }^{1 A} \&$ Abreu, F.C. ${ }^{1}$
}

${ }^{1}$ Instituto de Quimica e Biotecnologia- Universidade Federal de Alagoas, Maceió, Brazil, ${ }^{2}$ Centro de Ciências Biologicas da Saúde - Universidade Federal de Alagoas, Maceió, Brazil.

${ }^{3}$ Centro de Ciências Agrárias - Universidade Federal de Alagoas, Maceió, Brazil.

(Received January 27, 2017; Accept September 14, 2017)

\begin{abstract}
The herbicide trifluralin is one of the most widely herbicides used in weed control. This study aims to evaluate the genotoxic potential of the trifluralin herbicide on the Colossoma macropomum (tambaqui) using a multi-biomarker approach. The $C$. macropomum is highly adapted and predominant species in a variety of water bodies in the delta region of the São Francisco River and other river systems in Brazil. The mutagenic and the genotoxic effects of different trifluralin concentrations $(0.25$, $\left.0.5,0.75,1.0 \mathrm{mg} \mathrm{L}^{-1}\right)$ in peripheral erythrocytes of C. macropomum were investigated using micronucleus (MN), comet assay and apoptosis test. After an exposure period of $96 \mathrm{~h}$, the results showed a significant rate of micronuclei and nuclear abnormalities in erythrocytes of C. macropomum exposed to $0.5,0.75,1.0 \mathrm{mg} \mathrm{L}^{-1}$ of trifluralin. Compared to controls, the genetic damage index (GDI) showed significant variations $(* * p<0.01$ and $* * * p<0.001)$ for all the trifluralin concentrations tested. The genotoxicity of trifluralin herbicide on C. macropomum was confirmed by the micronucleus test and comet assay.
\end{abstract}

Keywords: Freshwater fish, herbicide, DNA damage, Colossoma macropomum, micronucleus test

\section{INTRODUCTION}

Over the past decades, the development and use of pesticides have increased in developing countries; however pesticides may produce a disruption of the ecological balance, causing damage to non-targeted organisms such as fish (Moraes, 2007; Mosesso, 2012). Contamination of surface waters by herbicides derived from agricultural practices is a problem of worldwide importance and their impact on aquatic organisms needs to be tightly monitored by governmental agencies (Miron, 2005).

In addition to this problem, several herbicides have already been found to be toxic to aquatic organisms. This type of contamination may pose a severe environmental risk to aquatic ecosystems (Guilherme et al. 2014). The application of pesticides over agriculture areas may endanger aquatic biota and fish farms (Martins \& Bianchini, 2011) due to the proximity of the aquatic ecosystem to farmlands in Brazil. For instance, the São Francisco River basin area in Northeast Brazil has high water demand due to the irrigated agriculture and agriculture impacts from the use of pesticides on irrigated perimeters. Trifluralin $(\alpha, \alpha, \alpha$ - trifluoro-2,6-dinitro$\mathrm{N}, \mathrm{N}$-dipropyl-p-toluidine) is regard as one of the most used herbicides in the region. Sugar-cane production is also widely spread in the region and herbicides, containing trifluralin, are commonly used to control grasses in this crop.

Trifluralin is a selective herbicide used to control many annual grasses and broadleaf weeds on a large variety of 
fruit trees, nuts, vegetables, and grain crops, including soybeans, sunflowers, cotton. Trifluralin inhibits microtubule polymerization, causing physical misconfiguration and loss of function. $\mathrm{NH}_{2}$ hydrogen of trifluralin binds the polar group of cellular membranes leading disorganization in the membrane structure, resulting in changes of the quantity of free $\mathrm{Ca}^{2+}$ in cytoplasm that have influence on polymerization and depolymerization regulation of the microtubules (Argese et al. 2002).

The herbicide is classified as highly toxic to fish and other aquatic organisms as demonstrated in several previous studies (EPA, 1996; Könen \& Çavas, 2008; Hartless et al. 2009). The Genotoxic effects of trifluralin have been evaluated in plants and animals such Allium cepa and Oreochromis niloticus (Nile Tilapia) (Fernandes et al. 2007; Könen \& Çavas, 2008). In both organisms, trifluralin exposure increased the micronucleus frequencies.

The Micronuclei test (MN) is regarded as a useful method to evaluate the mutagenic potential of the environmental agents (Vicari et al. 2012). This assay has been successful used in fish to analyze in vivo the genotoxic effect of chemicals present in the aquatic environmental. Two possible mechanisms are responsible for MN formation: chromosomal breaks (clastogenesis) or disruption of the mitotic apparatus (aneugenesis) (Vicari et al. 2012). However, MN expression depends on the mitotic activity in the studied tissue, which may depends on a complex interaction of biotic and environmental parameters such as temperature, salinity and food availability (Bolognesi and Hayashi, 2011). Due to the broad-spectrum of DNA damage detection, Comet Assay (CA) is another valuable test employed in toxicological genetics studies. CA has already been recognized as one of the most sensitive methods for measuring DNA strand breaks that can be visualized by the increased migration of free DNA segments (Araldi et al. 2015). The Comet assay showed an excellent suitability for aquatic genotoxicity monitoring of carp (Cyprinus carpio), rainbow trout (Oncorhynchus mykiss), and clam (Spisula sachalinensis) (Kim \& Hyun, 2006). Based on the fact that a high level of DNA damage leads to cell apoptosis, the Comet assay has also been used to distinguish apoptotic from nonapoptotic cells (Singh, 2000). The Comet and diffusion assays in erythrocytes Nile Tilapia (Oreochromis niloticus) and African catfish (Clarias gariepinus) showed to be a useful technique for in situ genotoxic monitoring (Osman et al. 2012). However, remains some concerns over the methodology used, and the type and quality of data produced using Comet assay (Kumaravel et.al, 2009). Apoptosis is a general term used to describe a non-inflammatory programmed cell death. The initiation of apoptosis is regulated by external and internal signals, such as the activation of dead receptors, damage to DNA, and perturbation of the mitochondrial membrane (DíazResendiz et al. 2015).

The serrasalmid Colossoma macropomum (Cuvier, 1816) [Characiformes: Characidae: Serrasalmidae], commonly known as Tambaqui (Colossoma macropomum). The species developed several adaptations through evolutional process, associated with swimming ability that is highly correlated with their habitat use and feeding behavior (Siqueira-Souza et al. 2017). Adult fish feed mainly on fruit and seeds, while juveniles feed on zooplankton, insects, snails, and decaying vegetation (Valladão et al., 2016). C. macropomum was chosen to be the organism test because it is highly adapted and predominant species in a variety of water bodies in the delta region of the São Francisco River where it has been intensively cultivated by the federal agency Companhia de Desenvolvimento dos Vales do São Francisco e do Parnaiba (CODEVASF). C. macropomum is a highly commercialized specie in the whole region and became an important commodity around the São Francisco River delta.

In order to evaluate the genotoxic effect of pure trifluralin in C. macropomum erythrocytes, this work used a Micronuclei test, a Comet assay and an Apoptosis test to compare the multi-biomarker response in vivo in acute exposure. This multi-biomarker approach intended to evaluate the sensitivity of $C$. macropomum to the herbicide trifluralin.

\section{MATERIAL AND METHODS}

Details of this study were submitted and approved by the Ethics Commission on the use of animals from the Universidade Federal de Alagoas (Case No. 024854/201011).

\section{Chemicals}

All chemicals were obtained from commercial sources. Trifluralin ( $\alpha, \alpha, \alpha$ trifluoro - 2,6-dinitro-N, N - dipropylp-toluidine) (CAS number -8 1582-09 ), $99 \%$ purity was purchased from Sigma-Aldrich (St. Louis-MO, USA) and used as received, Disodium EDTA, Niclosamide (CAS 50-657), Dimethyl Sulfoxide (DMSO; $99.9 \%$ ), Sodium Chloride, detergent Triton X-100, Trizma, Sodium Hydroxide, low melting Agarose, Syber Green, Gyemsa, Methanol, Ammonium Acetate and Ethanol, were also purchased from Sigma-Aldrich (St. Louis-MO, USA).

\section{Animals and acclimation}

Colossoma macropomum (Family: Serrasalmidae, Order: characiformes), (weight $42.51 \pm 8.20 \mathrm{~g}$ and measuring $14.36 \pm$ $1.04 \mathrm{~cm}$ overall in length; $n=120$; mean $\pm \mathrm{SD}$ ), were supplied from the fish culture station of CHESF, the Hydroelectric Company of the São Francisco River. Before the exposure to herbicide, the fish were acclimated to laboratory conditions in $250 \mathrm{~L}$ tanks containing herbicide free dechlorinated tap water for 7 days at room temperature $\left(26.0 \pm 1.0^{\circ} \mathrm{C}\right)$ under a $12 \mathrm{~h}$ photoperiod (Fernandes et al. 2004). During the acclimation, the water quality were monitored as follows: water temperature was determined using an Instrutherm (São Paulo, Brazil) model TE-300 digital portable thermometer, $\mathrm{pH}$ was measured using an AZ Instrument (Taichung City, Taiwan) model 8651 portable $\mathrm{pH}$-meter, and dissolved oxygen was 
assessed using a Lutron Electronic Enterprise (Taipei, Taiwan) model DO- 5510 digital oxygen meter. The water tank was continuously aerated using a static pump system according to the specifications of the ABNT NBR 15088 (2016). The fish were fed once a day with commercial fish pellets (38 \% crude protein).

\section{Toxicity test}

After the acclimation, the fish were randomly transferred to tank of $70 \mathrm{~L}$ (6 fish per tank) and exposed to trifluralin for 96 hours, following the guidelines of the ABNT NBR 15088 (2016). Fingerlings were distributed into six groups of six animals, four of them according to the concentration of trifluralin ( $0.25,0.5,0.75$ and $\left.1.0 \mathrm{mg} \mathrm{L}^{-1}\right)$ and two controls; Negative control (water and dimethylsulfoxide - DMSO $0.001 \%$ ), Positive control (Niclosamide - $3.0 \mu \mathrm{g} \mathrm{mL} \mathrm{m}^{-1}$ ) based on Monkiedje et al. (1991). The range of exposure concentrations tested was obtained from CL50-96 h (0.42 $\mathrm{mg} / \mathrm{L}$ ) previously determined by our group through acute exposure in static system (Silva et al. 2015). Since trifluralin has low water solubility $\left(0.3 \mathrm{mg} \mathrm{L}^{-1}\right.$ at $25{ }^{\circ} \mathrm{C}$, CAS\#1582-0908), stock solutions of the herbicide were prepared in DMSO and diluted appropriately so that the concentration of the solvent in the aquarium was $0.001 \%(\mathrm{v} / \mathrm{v})$. The aquaria were kept under constant aeration and oxygen levels maintained close to saturation. Water quality was monitored throughout the assays as described on acclimation and the conditions were recorded every 24 hours. Each assay was replicated four times, and the fish remained unfed during the assays.-

After 96 hours of exposure to the herbicide, the specimens were removed and placed in an ice bath (Menéndez-Helman et al. 2015). An incision was made below the operculum of the fish to sample blood for the Comet assay, Micronucleus test and Apoptosis according to Watson et al. (1989). A volume of $50 \mu \mathrm{L}$ of the sampled blood was transferred to a vial and added to phosphate-buffered saline (PBS) containing $20 \mathrm{mM}$ EDTA in a ratio of 5:1 to avoid coagulation before the Comet assay and Micronuclei tests.

\section{Micronucleus test and erythrocyte nuclear abnormalities (ENAs)}

The Micronucleus test was performed according to Hooftman \& Raat (1982). Immediately after collecting the blood samples, they were smeared onto a glass slides and then left to dry overnight. After fixed in pure methanol for 10 minutes, the slides were stained with $5 \%(\mathrm{v} / \mathrm{v})$ Giemsa for 20 minutes, washed with distilled water and left to dry in laboratory environment. To detect micronuclei in erythrocytes, the slides were examined under oil immersion at $100 \mathrm{X}$ magnification using a Labomed Lx 400 binocular microscope (Labo America, Fremont, CA, USA). In order to detect the frequency of micronuclei, each fish had 1800 erythrocytes examined per slide (being analyzed one slide per animal totalizing 6 slides per treatment).
Micronucleus and other abnormalities were identified following the criteria proposed by Carrasco et al. (1990) and Matsumoto et al. (2006). The MN frequency was calculated as:

$\% \mathrm{MN}=$ Number of cells containing micronucleus / total number of cells counted (Al-Sabti \& Metcalfe, 1995).

\section{Comet assay}

The alkaline version of the Comet assay was performed according to Singh et al. (1988) and Tice et al. (2000), with some adaptations. Each blood sample was diluted 8 times in PBS containing EDTA $(20 \mathrm{mM})$. The diluted blood sample was homogenized in PBS (1: 10) containing $0.5 \%$ low-melting point agarose (LMP - SIGMA-ALDRICH ${ }^{\circledR}$ ) and an aliquote of $40 \mu \mathrm{L}$ of this was layered on slides previously coated (the slides were pre-coated with $1.0 \%$ standard agarose SIGMAALDRICH in PBS). The procedure was done in duplicate. The slides were covered with coverslips then kept for $5 \mathrm{~min}$ in a refrigerator to solidify and then they were subsequently coated with an additional layer of $40 \mu \mathrm{L}$ of LMP agarose was added and cooled at $4^{\circ} \mathrm{C}$ for 5 minutes. After solidification, the embedded cells were immersed in a lysing buffer $(2.5$ $\mathrm{M} \mathrm{NaCl}, 10 \mathrm{mM}$ Tris, $100 \mathrm{mM}$ ethylenediaminetetra acetic acid-EDTA), $10 \%$ dimethyl sulphoxide, $1 \%$ Triton X-100, final $\mathrm{pH} 10.0$ ) for 1 hour at $4^{\circ} \mathrm{C}$. After the lyses, the slides were transferred to a horizontal gel electrophoresis tank containing a fresh alkaline electrophoresis buffer $(0.3 \mathrm{M}$ $\mathrm{NaOH}, 1 \mathrm{mM}$ EDTA, $\mathrm{pH}$ 13) and incubated for $20 \mathrm{~min}$ at $4^{\circ} \mathrm{C}$. The electrophoresis was carried out at $20 \mathrm{~V}$ and 300 $\mathrm{mA}$ for 20 minutes. After the electrophoresis, the slides were neutralized (Tris $0.4 \mathrm{M}, \mathrm{pH} 7.5$ ) and stained with SYBER Green (Invitrogen ${ }^{\mathrm{TM}}$ ) previously diluted in PBS (1: 200) for 10 min to visualize single DNA strand breaks. Slides were examined using an Olympus BX41 fluorescent microscope (Shinjuku, Tokyo) using a wavelength of $510-550 \mathrm{~nm}$. One hundred cells ( 100 per slides and 6 slides per treatment) were scored at $400 \mathrm{X}$ magnification.

The DNA damage was quantified by visually classifying cells into categories representing different degrees of DNA damage, ranging from non-visible migration 0 , Class 0 (undamaged); I, Class 1 (low damage, or equal to the diameter of one nucleus); II, Class 2 (medium damage, greater than the diameter of two nuclei ); III, Class 3 (extensive damage - greater than two times the diameter of one nucleus) and IV, Class 4 (complete damage) (Çavas \& Konen, 2007; Kobayashi et al. 1995).

The extent of DNA damage was expressed as the average percentage of cells with damage Types 0, I and II (Çavas, 2011) which was calculated as the sum of cells with damage. The genetic damage index (GDI) was calculated by the arbitrary values assigned to the different categories (class 0 to class 3 ) for each class.

$\mathrm{GDI}=\left(\begin{array}{lll}0 & x & n_{0}\end{array}\right)+\left(\begin{array}{lll}1 & x & n_{1}\end{array}\right)+\left(\begin{array}{lll}2 & x & n_{2}\end{array}\right)+\left(\begin{array}{lll}3 & x & n_{3}\end{array}\right)$, where $n$ $=$ number of cells in each class analyzed. Thus, the damage 
index could range from 0 (100 cells without damage) to 300 (all cells with damage class 3) (Manoharan \& Banerjee, 1985).

\section{Apoptosis test}

The apoptosis test (gel diffusion test) was performed according to Singh (2000) with some adaptations. The procedures were performed according to Comet assay until the lysis step. Then, the slides were immersed in a plastic container filled with a freshly made alkaline solution $(0.3 \mathrm{~N} \mathrm{NaOH}$ and $0.2 \% \mathrm{DMSO}, \mathrm{pH} 13$. for $10 \mathrm{~min}$ at room temperature 5 (Singh, 2000). After that, they were immersed for $15 \mathrm{~min}$ in $1 \mathrm{M}$ ammonium acetate solution in ethanol $(5 \mathrm{ml}$ of $10 \mathrm{M}$ ammonium acetate and $45 \mathrm{ml}$ of absolute ethanol). Further, they were immersed in a solution of $1 \mathrm{M}$ ammonium acetate in $90 \%$ ethanol for 15 minutes, followed by immersion in 75 $\%$ ethanol for 15 minutes. Then, the slides were allowed to dry at room temperature before being stained with SYBER Green (Invitrogene TM) diluted in PBS (1:200) for 10 minutes.

To detect apoptotic cells in erythrocytes, the slides were examined using an Olympus BX41 fluorescent microscope (Shinjuku, Tokyo) using a wavelength of 510-550 $\mathrm{nm}$. One hundred cells ( 100 per slides and 6 slides per treatment) were scored at $400 \mathrm{X}$ magnification. The classification was done with the presence or absence of halos around each nucleoid (Hooftman \& De Raat, 1982).

\section{Statistical Analysis}

All obtained data were submitted to a KolmogorovSmirnov test to determine the normality of data and the Cochran $\mathrm{C}$ test was employed to verify the homogeneity of variances. Data were expressed as mean \pm standard deviation, and average values were compared using one-way analysis of variance (ANOVA) and the Dunnett's test. The difference between the data of the Comet assay, Micronucleus and Apoptosis tests were analyzed between the control group and the experimental group with the same concentrations of trifluralin. The differences were considered statistically significant at the probability level $(p<0.05)$.

\section{RESULTS}

\section{Physicochemical parameters of water}

Water quality, expressed in terms of temperature, $\mathrm{pH}$ and dissolved oxygen, exhibited no significant differences (Dunnett test) between the $96 \mathrm{~h}$ toxicity tests with trifluralin, and the average values of the parameters were $26.48 \pm 0.17^{\circ} \mathrm{C}, \mathrm{pH} 7.10 \pm$ 0.35 and $7.00 \pm 0.29 \mathrm{mg} \mathrm{L}^{-1}$ of dissolved oxygen, respectively. No fish mortality was observed during the $96 \mathrm{~h}$ period of exposure.

\section{Micronucleus test}

Compared to the negative control, the peripheral erythrocytes from C. macropomum exposed to different
TRF concentrations $\left(0.5,0.75\right.$ e $\left.1.0 \mathrm{mg} \mathrm{L} \mathrm{L}^{-1}\right)$ and positive control for $96 \mathrm{~h}$ showed significant variations $(\mathrm{p}<0.05)$ on the frequency of micronuclei for all the concentrations except for the $0.25 \mathrm{mg} \mathrm{L}^{-1}$ exposure on Table 1 . The highest frequency was obtained on $0.5 \mathrm{mg} \mathrm{L}^{-1}$ of TRF exposure. The frequency of micronucleus obtained on this exposure is comparable to the value obtained on the positive control (niclosamide $3 \mu \mathrm{g}$ $\mathrm{mL}^{-1}$ ). Micronuclei and other nuclear alterations could be identified on the C. macropomum erythrocytes submitted to the TRF exposition tested in Fig. 1.

Table 1. Frequency of micronucleus in peripheral Erythrocytes of the $C$. macropomum exposed to different trifluralin concentrations for 96 hours.

\section{Treatments}

${ }^{1}$ Negative Control

${ }^{2}$ Positive Control

$0.25 \mathrm{mg} \mathrm{L}^{-1}$

$0.5 \mathrm{mg} \mathrm{L}^{-1}$

$0.75 \mathrm{mg} \mathrm{L}^{-1}$

$1.0 \mathrm{mg} \mathrm{L}^{-1}$
Source: Equation $\left.\left(\mathrm{N}_{\mathrm{MN}} / \mathrm{N}_{\mathrm{N}}\right) * 100 \%\right)$, the fish were kept in ${ }^{1}$ Negative control (water and dimethylsulfoxide - DMSO 0.001\%), ${ }^{2}$ Positive control (Niclosamide - $3.0 \mu \mathrm{g} \mathrm{mL} \mathrm{mL}^{-1}$ ) SEM: standard error of mean. The statistical analysis used was one-way ANOVA with Dunnett's test * $\mathrm{p}<0.05$ compared to negative control.
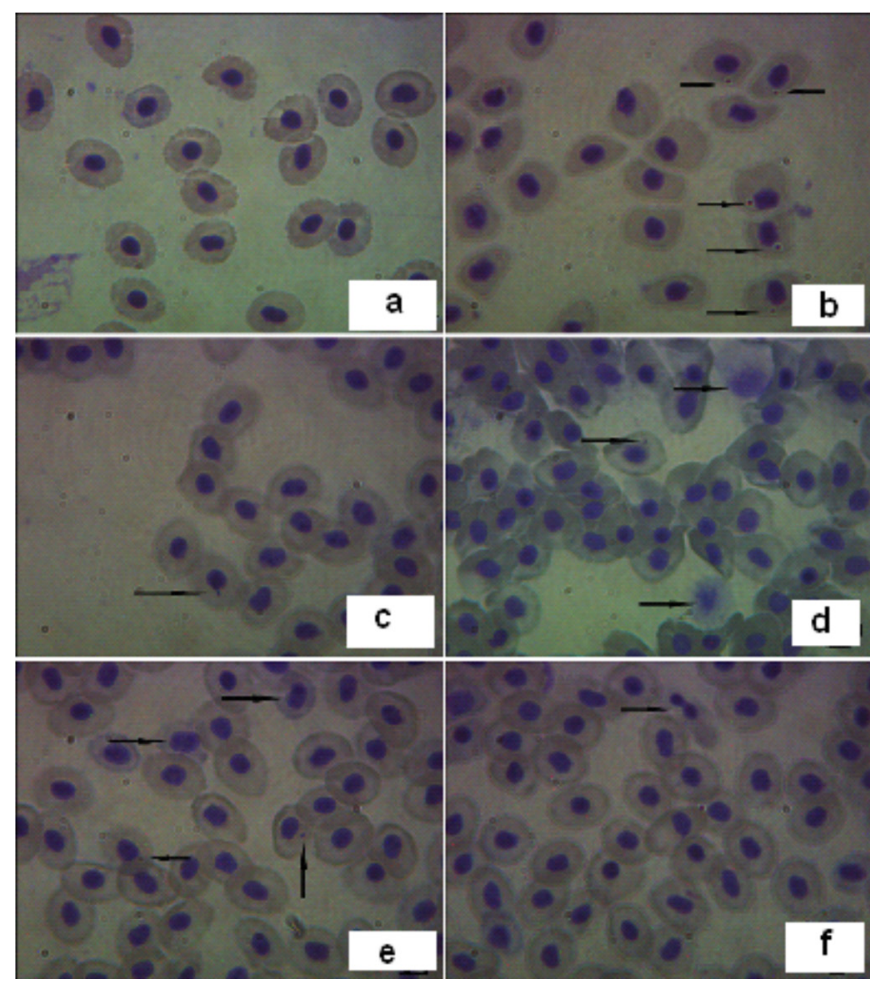

Figure 1. Micronuclei and nuclear abnormalities found in peripheral erythrocytes of the C. macropomum exposed to trifluralin herbicide. (a) Cells without micronucleus; (b) cells with micronucleus; (c) cells with "lobed" nucleus; (d) cells with micronucleus and cells in apoptosis; (e) cells with micronucleus and cells with nuclear abnormalities; (f) binucleated cells. 


\section{Comet assay}

The results of the Comet assay of the erythrocytes of C. macropomum exposed for $96 \mathrm{~h}$ to different TRF concentrations $\left(0.25,0.5,0.75,1.0 \mathrm{mg} \mathrm{L}^{-1}\right)$, negative control and positive control presented the highest proportion on class 0 for the damaged nuclei (\%). A much lower proportion of damaged nuclei (\%) was also observed on class 1 . On concentrations of 0.5 and $1.0 \mathrm{mg}$ $\mathrm{L}^{-1}$ of TRF were observed frequency of nucleoids with medium damage (class 2). Compared to negative control, the genetic damage index (GDI) showed significant variations $(* * \mathrm{p}<0.01$ and $* * * p<0.001)$ for the all the TRF concentrations tested in Fig. 2. On the exposures of 0.25 and $0.75 \mathrm{mg} \mathrm{L}^{-1} \mathrm{TRF}$, a higher GDI $(p<0.001)$ was observed. The values of GDI obtained on these

\section{Comet Assay}

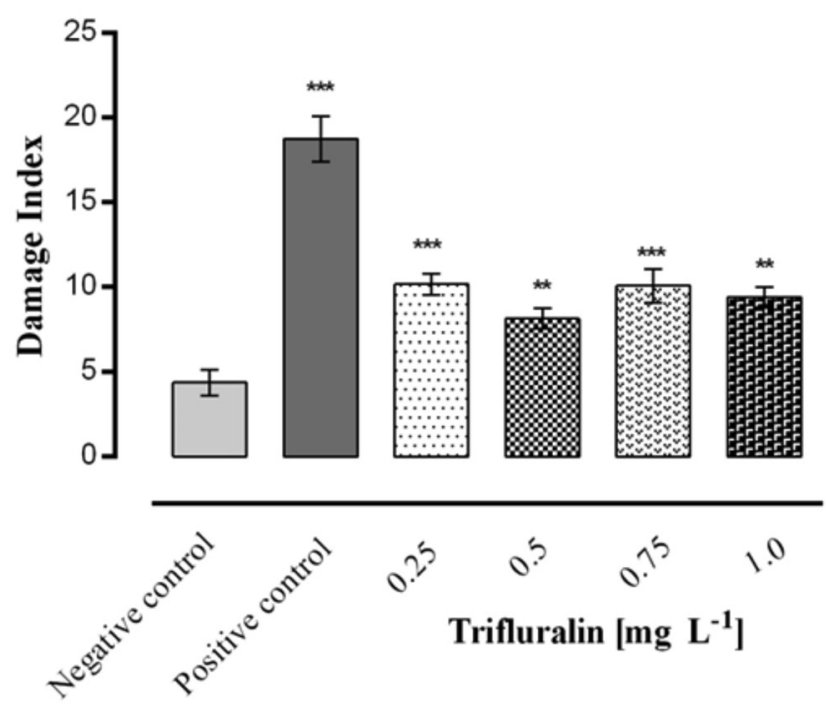

Figure 2. Mean values of DNA damage, expressed damage index, measured by the Comet assay in peripheral blood Erythrocytes of the C. macropomum exposed to different concentrations trifluralin for 96 hours. The statistical analysis used was the one-way ANOVA with post test Dunnett's ** p < $0.01 ; * * * \mathrm{p}<0.001$ compared to negative control. concentrations are comparable to the value obtained on the positive control (niclosamide $3 \mu \mathrm{g} \mathrm{L}-{ }^{1}$ ). The results are summarized in Table 2.

\section{Apoptosis test}

The frequency distributions of the apoptotic nuclei detected in erythrocytes of C.macropomum exposed for $96 \mathrm{~h}$ to different TRF concentrations $(0.25,0.5,0.75,1.0$ $\mathrm{mg} \mathrm{L}^{-1}$ ), negative control and positive control by diffusion assays shown in Table 3. Compared to the negative control, significant $(p<0.05)$ variations of the frequency distributions of the apoptotic nuclei were observed on the positive control and on the $0.5 \mathrm{mg} \mathrm{L}^{-1} \mathrm{TRF}$ exposure.

\section{DISCUSSION}

The biomonitoring genotoxicity in aquatic organisms is very important for several reason: protection of genetic diversity in natural populations for maintain of population survival, detection of carcinogenic effects in aquatic organisms to assess the health of aquatic organisms, as well as to prevent carcinogens from entering the food chain to humans (Jha et al. 2000). In the last decades, many in-vivo and in-situ studies have been carried out on fishes to investigate genotoxic effects. From more than three decades, micronucleus (MN) test, one of those most frequently used in environmental genotoxicity studies to evaluate chromosomal breaks or cell spindle malfunction, serving as an index of cytogenetic damage (COSTA et al. 2011). Among the genotoxicity tests, comet assay has been widely used to investigate the impacts of environmental contaminants on DNA lesions by monitoring and biomonitoring program in fishes (Osman et al. 2014). Comet assays has also employed to visualize DNA degradation due to apoptosis. High levels of DNA damage can lead to cell apoptosis.

In this study, C. macropomum was exposed to higher trifluralin concentrations $\left(0.25,0.5,0.75,1.0 \mathrm{mg} \mathrm{L}^{-1}\right)$,

Table 2. Mean frequency of each class of DNA damage ( \pm standard error of mean) determined by the Comet assay in peripheral Erythrocytes of the $C$. macropomum exposed to different trifluralin concentrations for 96 hours.

\begin{tabular}{lccccc}
\hline & Level 0 & Level 1 & Level 2 & Level 3 & \% of Damaged Cells \\
\cline { 2 - 6 } Treatment & Mean \pm SE & Mean \pm SE & Mean \pm SE & Mean \pm SE & Mean \pm SE \\
\hline${ }^{1}$ Negative Control & $95.63 \pm 1.35$ & $4.38 \pm 1.35$ & $0.00 \pm 0.00$ & $0.00 \pm 0.00$ & $4.38 \pm 1.35$ \\
${ }^{2}$ Positive Control & $82.67 \pm 1.54$ & $15.92 \pm 1.56$ & $1.42 \pm 0.38$ & $0.00 \pm 0.00$ & $18.75 \pm 2.32^{* * *}$ \\
$0.25 \mathrm{mg} \mathrm{L}^{-1}$ & $89.82 \pm 1.09$ & $10.18 \pm 1.09$ & $0.00 \pm 0.00$ & $0.00 \pm 0.00$ & $10.18 \pm 1.09^{* * *}$ \\
$0.50 \mathrm{mg} \mathrm{L}^{-1}$ & $91.93 \pm 0.94$ & $8.00 \pm 0.91$ & $0.07 \pm 0.07$ & $0.00 \pm 0.00$ & $8.14 \pm 1.05^{* *}$ \\
$0.75 \mathrm{mg} \mathrm{L}^{-1}$ & $89.93 \pm 1.72$ & $10.07 \pm 1.72$ & $0.00 \pm 0.00$ & $0.00 \pm 0.00$ & $10.07 \pm 1.72^{* * *}$ \\
$1.00 \mathrm{mg} \mathrm{L}^{-1}$ & $90.65 \pm 0.92$ & $9.30 \pm 0.92$ & $0.05 \pm 0.05$ & $0.00 \pm 0.00$ & $9.40 \pm 1.02^{* *}$ \\
\hline
\end{tabular}

Note: Fish were kept in ${ }^{1}$ Negative control (water and dimethylsulfoxide - DMSO, 0.001\%), ${ }^{2}$ Positive control (Niclosamide - $3.0 \mu \mathrm{g} \mathrm{mL}^{-1}$ ). SEM: standard error of mean; DC: rate of damaged cells; GDI: genetic damage index. The statistical analysis used was the one-way ANOVA with post test Dunnett's ** $\mathrm{p}<$ $0.01 ; * * * \mathrm{p}<0.001$ compared to negative control. 
Table 3. Mean values of viable and apoptotic erythrocyte cells of the C. macropomum and their respective percentages after exposed to different trifluralin concentrations for 96 hours.

\begin{tabular}{lcccc}
\hline Treatments & Viable & Apoptosis & \% Viable & \% Apoptosis \\
\hline${ }^{1}$ Negative Control & $371.6 \pm 38$ & $3.90 \pm 2.23$ & 99.06 & 0.94 \\
Positive Control & $390.0 \pm 5.7$ & $9.60 \pm 3.95$ & 97.54 & $2.46^{* *}$ \\
$0.25 \mathrm{mg} \mathrm{L}^{-1}$ & $383.6 \pm 29$ & $2.27 \pm 1.88$ & 99.35 & 0.65 \\
$0.5 \mathrm{mg} \mathrm{L}^{-1}$ & $323.6 \pm 88$ & $8.70 \pm 4.00$ & 97.89 & $2.11^{* *}$ \\
$0.75 \mathrm{mg} \mathrm{L}^{-1}$ & $338.6 \pm 71$ & $4.50 \pm 3.57$ & 98.95 & 1.05 \\
$1.0 \mathrm{mg} \mathrm{L}^{-1}$ & $345.6 \pm 66$ & $4.33 \pm 2.74$ & 98.96 & 1.04 \\
\hline
\end{tabular}

Source: The fish were kept in ${ }^{\mathrm{I}}$ Negative control (water and dimethylsulfoxide - DMSO 0.001\%), ${ }^{2}$ Positive control (Niclosamide - 3.0 $\mu \mathrm{g} \mathrm{mL}{ }^{-1}$ ), SEM: standard error of mean. The statistical analysis used was the one-way ANOVA with Dunnett's multiple comparisons test ** $\mathrm{p}<0.01$ compared to negative control.

however only $0.25 \mathrm{mg} \mathrm{L}-1$ of TRF exposure induced no significant increase in MN on erythrocytes for the time tested. Since a latency period is required between exposure treatment and subsequent $\mathrm{MN}$ peak. In case of fish, the maximal MN induction occurs 1-5 days (Kumar, 2013). The design of present study with an exposure period of $96 \mathrm{~h}$, at constant temperature, followed by subsequent harvesting is in accordance with the time required maximal $\mathrm{MN}$ induction in fish. Then, the relatively low levels of MN detected for the $0.25 \mathrm{mg} \mathrm{L}^{-1} \mathrm{TRF}$ exposure could be related to the fact of this concentration alone was not sufficiently high enough dosage to induce $\mathrm{MN}$ in erythrocytes of C. macropomum, due to the internal physiological and biochemical characteristics of the species studied. The kinetics of the cell proliferation may vary among fish species and depending on their target tissue and environmental conditions (Obiakor et al. 2012; AI-Sabti \& Metcalfe, 1995; Bücker et al. 2012). Several studies have also analyzed the simultaneous expression of morphological nuclear abnormalities-NAs together with micronuclei (Çavas \& Ergene-Gozukara, 2005; Ventura et al. 2008). Those studies indicated that NAs are induced in response to the exposure to genotoxic agents. In this work, different kind of NAs were also identified such as cells with lobed nucleus, binucleated cells and cells in apoptosis in erythrocytes of C. macropomum after $96 \mathrm{~h}$ exposure to different TRF concentration confirming the genotoxic effect of the herbicide on this species.

The occurrence of micronuclei can be an indicator of clastogenic as well as aneugenic effects.

The clastogenic effects can be confirmed by the presence of micronuclei which might be derived from chromosomal breaks during cell division is a confirmation of clastogenic action while the aneugenic action is a consequence of the inactive mitotic fuse, leading to losses of entire chromosomes, which become absent in the main cell nucleus. Another studies have shown that the trifluralin herbicide induced the micronuclei formation on Allium cepa due to its aneugenic action. The aneugenic activity of the TRF in plants is related to its ability to inhibit microtubule polymerization leading to physical misconfiguration and loss of function. Dinitroaniline herbicides have a higher specificity for binding to the plant tubulins than vertebrate tubulins those of vertebrates (Fernandes et al. 2013). Concentrations of 0.42 and $0.84 \mathrm{mg} \mathrm{L}^{-1}$ TRF lead to several irregularities in Allium cepa, such as chromosomal and nuclear alterations in Allium cepa showing reliable informations about the genetic damage, mainly on chromosomes (Fernandes et al. 2009). In this study, erythrocytes of C. macropomum showed the highest frequency of micronucleus in $0.5 \mathrm{mg} \mathrm{L}^{-1} \mathrm{TRF}$ exposure. Dimitrov et al. (2006) identified different genotoxic responses of plant and mouse bone marrow exposed to the dinitroaniline herbicide Stomp 330. This herbicide increased the frequency of micronuclei in both test systems however did not show chromosomal aberrations in plant cells (Crepis capillaris L.) At the highest concentration used $\left(0.489 \mathrm{~g} \mathrm{~L}^{-1}\right.$ Stromp) was observed an increase in chromosomal aberrations in mouse bone marrow, indicating that the micronuclei produced by Stomp 330 in mouse bone marrow cells resulted from a clastogenic effect.

The Comet assay is regarded as a good nonspecific biomarker to detect genotoxicity in aquatic species. This assay has been successfully applied in erythrocytes of several fish species exposed to the different genotoxic agents. The assay allows evaluating the DNA strand breaks on organisms due to the exposure of xenobiotics (Ahmad \& Ahmad, 2015). The damaged nucleoid classes were analyzed individually to better understand the behavior of the DNA damage on erythrocytes of C. macropomum exposed to TRF concentrations, which shows that the damage levels did not increase with the rise of the TRF concentrations on the exposure time used in this study. Compared to negative control, GDI showed significant variations for all TRF exposures, thus indicating the genotoxic potential of TRF to C. macropomum. However, the TRF did not induced a concentration-dependent increase in DNA single-strand breaks in the form of comet induction. Another studies employing Comet assays showed that trifluralin around $5 \mu \mathrm{g} \mathrm{mL}^{-1}$ induced DNA damage in human lymphocytes leading significant increase in the tail length (Ribas et.al., 1995) indicating a clastogenic effect of this herbicide. The results of the frequency distributions of the apoptotic nuclei detected in erythrocytes of C. macropomum exposed to TRF concentrations showed that the $0.5 \mathrm{mg}$ of exposure induced an apoptosis frequency comparable to the value obtained for 3 $\mu \mathrm{g} \mathrm{mL}{ }^{-1}$ niclosamide (positive control). According to the EPA (1999), niclosamide is classified as highly toxic to very highly toxic for freshwater fish species. Niclosamide also induced apoptotic cell death; in cells treated with niclosamide $(0.327$ $\mathrm{mg} \mathrm{L}^{-1}$ and $3.27 \mathrm{mg} \mathrm{L}^{-1}$ ) (Park et al. 2011). 


\section{CONCLUSION}

Among the three methods employed in this study, the MN test and the Comet assay were able to identify the genotoxic potential of trifluralin in erythrocytes of C. macropomum. The highest frequency of micronucleus in peripheral erythrocytes of C. macropomum was obtained in the 0.5 $\mathrm{mg} \mathrm{L}^{-1}$ exposure. This concentration falls on the range of dinitroaniline herbicides concentrations that are genotoxic for plants A.cepa $\left(0.42,0.84 \mathrm{mg} \mathrm{L}^{-1}\right.$ trifluralin) and mouse bone marrow polychromatic erythrocytes $\left(0.489 \mathrm{mg} \mathrm{L}^{-1}\right.$ Stromp 330). With regards to the Comet assay, it is an efficient indication of genotoxicity of trifluralin in C. macropomum. Since all the tested concentrations of trifluralin herbicide induced mutagenic and genotoxic effects in C. macropomum. Although C. macropomum is well adapted to Brazilian rivers, this species has moderate sensitivity to trifluralin and it might be not suitable to be employed as a sentinel for biomonitoring genotoxicity contamination by the dinitroaniline herbicides in the São Francisco River delta as well as in other water bodies.

\section{ACKNOWLEDGMENTS}

We would like to thank the Conselho Nacional de Desenvolvimento Científico e Tecnológico (CNPq) for the financial support in this study and the Coordenação de Aperfeiçoamento de Pessoal de Nível Superior (CAPES) for the scholarship awarded to JMS. We are also grateful to the Companhia Hidroelétrica do São Francisco (CHESF) for supplying the fish employed in the experiments.

\section{REFERENCES}

ASSOCIAÇÃO BRASILEIRA DE NORMAS TÉCNICAS - ABNT NBR 15088:2016 - Ecotoxicologia aquática - Toxicidade aguda - Método de ensaio com peixes (Cyprinidae), que revisa a norma ABNT NBR 15088:2011, elaborada pela Comissão de Estudo Especial de Análises Ecotoxicológicas (ABNT/CEE-106).

ARALDI, R.P., MELO, T.C., MENDES, T.B., JUNIOR, P.L.S., NOZIMA, B.H.N., ITO, E. T., CARVALHO, R.F., SOUZA, E.B., STOCCO, R.C. 2015. Using the Comet and Micronucleus assays for genotoxicity studies: A review. Biomed. \& Pharmacol. 72:74-82. doi: 10.1016/j.biopha.2015.04.004.

AHMAD, I. \& AHMAD, M. 2016. Fresh water Fish, Channa Punctatus, as a Model for Pendimethalin Genotoxicity Testing: A New Approach toward Aquatic Environmental Contaminants. Environ. Toxicol., 31(11):1520-1529. doi: 10.1002/tox.

ARGESE, E., BETTIOL, C., FASOLO, M., ZAMBON, A., AGNOLI, F. 2002. Substituted aniline interaction with submitochondrial particles and quantitative structure-activity relationships. Biochim. Biophys. Acta, 1558:151-160. doi:10.1016/S00052736(01)00424-2

AL-SABTI, K. \& METCALFE, C. D. 1995. Fish micronuclei for assessing genotoxicity in water. Mutat. Res., 323:121-135. doi: 10.1016/0165-1218(95)90078-0.

BOLOGNESI, C. \& HAYASHI, M. 2011. Micronucleus assay in aquatic animals. Mutagenesis, 26:205-213. doi:10.1093/mutage/ geq073.

BÜCKER, A., CARVALHO, M. S., CONCEIÇÃO, M.B., ALVES-
GOMES, J. A. 2012. Micronucleus test and Comet assay in erythrocytes of the Amazonian electric fish Apteronotus bonapartii exposed to benzene. J. Braz. Soc. Ecotoxicol., 7:6573. doi:10.5132/jbse.2012.01.010.

CARRASCO, K.R., TILBURY, K. L., MAYERS, M. S. 1990. Assessment of the piscine micronuclei test as an in situ biological indicator of chemical contaminants effects. Can. J. Fish Aquat. Sci. 47:2123-2136. doi:10.1139/f90-237.

ÇAVAS, T. \& ERGENE-GOZUKARA, S. 2005. Micronucleus test in fish cells: a bioassay for in situ monitoring of genotoxic pollution in the marine environment. Environ. Mol. Mutagen. 46:64-70. doi:10.1002/em.20130.

ÇAVAS, T. \& KONEN, S. 2007. Detection of cytogenetic and DNA damage in peripheral erythrocytes of goldfish (Carassius auratus) exposed to a glyphosate formulation using the micronucleus test and the Comet assay. Mutagenesis 22:263-268. doi:10.1093/ mutage/gem012.

ÇAVAS T. 2011. In vivo genotoxicity evaluation of atrazine and atrazine-based on herbicide on fish Carassius auratus using the micronucleus test and the Comet assay. Food and Chem. Toxicol., 49:1431-1435. doi:10.1016/j.fct.2011.03.038.

COSTA, P.M., NEUPARTH, T.S., CAEIRRO, S., LOBO, J., MARTINS, M., FERREIRA, A.M., CAETANO, M., VALE, C., DELVAlLS, A., COSTA. M.H. 2011. Assessment of the genotoxic potential of contaminated estuarine sediments in fish peripheral blood: Laboratory versus in situ studies. Environ. Res. 111:25-36. doi:10.1016/j.envres.2010.09.011.

DÍAZ-RESENDIZ, K. J. G., TOLEDO-IBARRA, G.A., GIRÓNPÉREZ, M. I. 2015. Modulation of Immune Response by Organophosphorus Pesticides: Fish as a Potential Model in Immunotoxicology. J. Immunol. Res., 10:1-11. doi:10.1155/2015/213836.

DIMITROV, B.D.; GADEVA, P.G.; BENOVA, D.K., BINEVA, M.V. 2006. Comparative genotoxicity of the herbicides Roundup, Stomp and Reglone in plant and mammalian test systems. Mutagenesis, 21(6):375-382, doi: 10.1093/mutage/gel044.

USEPA (Environmental Protection Agency).1996. Reregistration Eligibility Decision (RED) Trifluralin. 738-R-95-040, Washington DC.

USEPA (Environmental Protection Agency).1999. Reregistration Eligibility Decision (CAS) Niclosamida. 738 F99 - 013, November, Washington DC.

FERNANDES, J.B.K., LOCHMANN, R., BOCANEGRA, F.A. 2004. Apparent digestible energy and nutrient digestibility coefficients of diet ingredients for pacu Piaractus brachypomus. J. World Aquacult. Soc., 35:237-244. doi:10.1111/j.1749-7345.2004. tb01080.x.

FERNANDES T.C.C., MAZZEO, D. E.C., MARIN-MORALES, M. A. 2007. Mechanism of micronuclei formation in polyploidizated cells of Allium cepa exposed to trifluralin herbicide. Pestic. Biochem. Physiol., 88:252-259. doi:10.1016/j. pestbp.2006.12.003.

FERNANDES, T. C. C., MAZZEO, D.E.C., MARIN-MORALES, M.A. 2009. Origin of nuclear and chromosomal alterations derived from the action of an aneugenic agent-Trifluralin herbicide. Ecotoxicol. Environ. Saf., 72:1680-1686. doi:10.1016/j.ecoenv.2009.03.014.

FERNANDES, T. C. C., PIZANO, M. A., MARIN-MORALES, M.A. 2013. "Characterization, Modes of Action and Effects of Trifluralin: A Review". 489-515. doi.org/10.5772/55169.

GUILHERME, S., SANTOS, M.A., ISABEL GAIVÃO, I., PACHECO, M. 2014. Genotoxicity Evaluation of the Herbicide Garlon ${ }^{\circledR}$ and Its Active Ingredient (Triclopyr) in Fish (Anguilla anguilla L.) Using the Comet Assay. Environ. Toxicol. 
30(9):1073-81. doi:10.1002/tox.

HARTLESS, C., JANSON, M., MILLER, R. 2009. Risks of trifluralin use to the federally listed California Red-legged Frog (Rana aurora draytonii), Delta Smelt (Hypomesus transpacificus), San Francisco Garter Snake (Thamnophis sirtalis tetrataenia), and San Joaquin Kit Fox (Vulpes macrotis mutica). Washington: Environmental Protection Agency, Environmental Fate and Effects Division Office of Pesticide Programs.

HOOFTMAN, R. N. \& DE RAAT, W. K. 1982. Induction of nuclear anomalies (micronuclei) in the peripheral blood erythrocytes of the eastern mudminnow Umbra pygmaea by ethyl methanesulphonate. Mutat. Res., 104:147-152. doi:10.1016/0165-7992(82)90136-1.

JHA, A.N.; CHEUNG, V.V.; FOULKES, M.E.; HILL, S.J.; MICHAEL H. DEPLEDGE, M.H. 2000. Detection of genotoxins in the marine environment: adoption and evaluation of an integrated approach using the embryo-larval stages of the marine mussel, Mytilus edulis. Mutat. Res., 464(2000):213-228. doi:10.1016/S1383-5718(99)00188-6.

MATSUMOTO, S.T., MANTOVANI, M.S., MALAGUTTII, M. I. A., DIAS, A. L., FONSECA, I. C., MARIN-MORALES, M. A. 2006. Genotoxicity and mutagenicity of water contaminated with tannery effluents, as evaluated by the micronucleus test and Comet assay using the fish Oreochromis niloticus and chromosome aberrations in onion root-tips. Genet. Molec. Biol., 29(1):148-158. doi:10.1590/S1415-47572006000100028.

MARTINS, S.E. \& BIANCHINI, A. 2011. Toxicity tests aiming to protect Brazilian aquatic systems: current status and implications for management. J. Environ. Monit. 13:18-66. doi:10.1039/ C0EM00787K.

MANOHARAN, K. \& BANERJEE, MR. 1985. b-Carotene reduces sister chromatid exchange induced chemical carcinogens in mouse mammary cells in organ culture. Cell Biol. Int. Rep., 9:783-789. doi:10.1016/0309-1651(85)90096-7.

MENÉNDEZ-HELMAN, R. J., FERREYROA, G.V., AFONSO, M.S., SALIBIÁN A. 2015. Circannual rhythms of acetylcholinesterase (AChE) activity in the freshwater fish Cnesterodon decemmaculatus. Ecotoxicol. Environ. Saf., 111:236-241. doi: 10.1016/j.ecoenv.2014.10.017.

MIRON, D. S., CRESTANI, M., SHETTINGER, M. R., MORSCH, V.M., BALDISSEROTTO, B., TIERNO, M. A., MORAES, G., VIEIRA, V.L.P. 2005. Effects of the herbicides clomazone, quinclorac, and metsulfuron methyl on acetylcholinesterase activity in the silver catfish (Rhamdia quelen) (Heptapteridae). Ecotoxicol. Environ. Saf., 61:398-403. doi:10.1016/j. ecoenv.2004.12.019.

MONKIEDJE, A., ANDERSON, A. C., ENGLANDE, A. J. 1991. Acute toxicity of Phytolacca dodecandra (Endod-S) and Niclosamide to snails, Schistosoma mansoni cercaria, Tilapia fish, and soil microorganisms. Environ. Toxicol. Water Quality. 4:405-413. doi:10.1002/tox.2530060405.

MORAES, B.S., LORO, V.L., GLUSCZAK, L., PRETTO, A., MENEZES, C., MARCHEZAN, E., MACHADO, S. O. 2007. Effects of four rice herbicides on some metabolic and toxicology parameters of teleost fish (Leporinus obtusidens). Chemosphere, 68:1597-1601. doi:10.1016/j.chemosphere.2007.03.006.

MOSSESO, P., ANGELETTI, D., PEPE, G., PRETTI, C., NASCETTI, G., BELLACIMA, R., CIMMARUTA, R., JHA, A.N. 2012. The use of cyprinodont fish, Aphanius fasciatus, as a sentinel organism to detect complex genotoxic mixtures in the coastal lagoon ecosystem. Mutat. Res. / Genetic Toxicol. Environ. Mutag. 742:31-36. doi:10.1016/j.mrgentox.2011.11.018.

KONEN, S. \& ÇAVAS, T. 2008. Genotoxicity testing of the herbicide trifluralin and its commercial formulation Treflan using the piscine micronucleus test. Environ. Mol. Mutagen. 6:434438. doi:10.1002/em.20401.

KOBAYASHI, H., SUGIYAMA, C., MORIKAWA, Y., HAYASHY, M., SOFUNI, T. 1995. A comparison between manual microscopic analysis and computerized image analysis in the single cell gel electrophoresis assay. MMS Commun., $3: 103-115$.

KIM, Y. \& HYUN, C. K. 2006. Comparative evaluation of the alkaline Comet assay with the micronucleus test for genotoxicity monitoring using aquatic organisms. Ecotoxicol. Environ. Saf., 64:288-297. doi:10.1016〉j.ecoenv.2005.05.019.

KUMAR, A., KESARI, V.P., KHAN, P.K. 2013. Fish micronucleus assay to assess genotoxic potential of arsenic at its guideline exposure in aquatic environment. Biometals. 26:337-346 doi: 10.1007/s10534-013-9620-8.

KUMARAVEL, T.S., VILHAR, B., FAUX, S.P., JHA, A.N. 2009. Comet Assay measurements: a perspective. Cell Biol. Toxicol. 25:53-64 doi: 10.1007/s10565-007-9043-9.

OBIAKOR, M. O., OKONKWO, J. C., NNABUDE, P.C., EZEONYEJIAKU, C. D. 2012. Eco-genotoxicology: Micronucleus Assay in Fish Erythrocytes as In situ Aquatic Pollution Biomarker: a Review. J. Anim. Sci. Adv., 2(1):123133. doi: 10.13140/2.1.2327.9040.

OSMAN, A.G.M. 2014. Genotoxicity Tests and Their Contributions in Aquatic Environmental Research. J. Environ. Protect., 5:13911399. doi:10.4236/jep.2014.514132.

OSMAN, A.G.M., ABUEL-FADL, K. Y. \& KLOAS, W. 2012. In situ evaluation of the genotoxic potential of the river Nile: II. Detection of DNA strand-breakage and apoptosis in Oreochromis niloticus (Linnaeus, 1758) and Clarias gariepinus (Burchell, 1822). Mutat. Res., 747:14-21. doi:10.4236/jep.2014.514132.

PARK, S. J., SHIN, J. H., KANG, H., HWANG, J. J., CHO, D.H. 2011. Niclosamide induces mitochondria fragmentation and promotes both apoptotic and autophagic cell death. Biochem. Mol. Biol. Int., 44 (8):517-522. doi:10.5483/BMBRep.2011.44.8.517.

RIBAS ,G., FRENZILLI, G., BARALE, R., MARCOS, R. 1995. Herbicide-induced DNA damage in human lymphocytes evaluated by the single-cell gel electrophoresis (SCGE) assay. Mutat. Res. 344(1-2):41-54. doi: 10.1016/0165-1218(95)900373.

SILVA, J.M., SANTOS, F. L. B., TENÓRIO, H. A., PEREIRA, H. J. V., COSTA, J.G., SANTANA, A. E. G., MACHADO, S.S., ABREU, F.C. 2015. In vivo and in vitro inhibition of cholinesterase activity in Colossoma macropomum (tambaqui) fingerlings by the herbicide trifluralin. Ecotoxicol. Environ. Contam., 10(1):23-30. doi: 10.5132/eec.2015.01.04.

SIQUEIRA-SOUZA, F. K., BAYERB, C., CALDASC, W. H., CARDOSOA, D. C., YAMAMOTOA, K. C., FREITASA, C. E. C. 2017. Ecomorphological correlates of twenty dominant fish species of Amazonian floodplain lakes. Braz. J. Biol. doi:10.1590/1519-6984.16215.

SINGH N. 2000. A Simple Method for Accurate Estimation of Apoptotic Cells. Experiment. Cell Res., 256:328-337.

SINGH, N.P., MCCOY, M. T., TICE, R. R., SCHNEIDER, E. L. 1988. A simple technique for quantification of low levels of DNA damage in individual cells. Exp. Cell Res., 175:184-491.

TICE R.R., AGURELL, E., ANDERSON, D., BURLINSON, B., HARTMANN, A., KOBAYASHI, H., MIYAMAE, Y., ROJAS, E., RYU, J.C., SASAKI, Y.F. 2000. Single cell gel/Comet assay: guidelines for in vitro and in vivo genetic toxicology testing. Environ. Mol. Mutagen., 35:206-221. doi:10.1002/(SICI)10982280(2000)35:3<206::AID-EM8>3.0.CO;2-J.

VALLADÃO, G., GALLANI, S.U., PILARSKI, F. 2016. South American fish for continental aquaculture. Reviews in 
Aquaculture (in press). 0: 1-19. doi: 10.1111/raq.12164.

VENTURA, B. C., ANGELIS, D. F., MARIN-MORALES, M. A. 2008. Mutagenic and genotoxic effects of the Atrazine herbicide in Oreochromis niloticus (Perciformes, Cichlidae) detected by the micronuclei test and the Comet assay. Pestic. Biochem. Physiol. 90: 42-51. doi:10.1016/j.pestbp.2007.07.009.

VICARI, T., FERRARO, M.V.M., RAMSDORF, W. A., MELA,
M., RIBEIRO, C.A.O., CESTARI, M.M. 2012. Genotoxic evaluation of different dosages of methylmercury (CH3Hgp) in Hoplias malabaricus. Ecotoxicol. Environ. Saf., 82:47-55. doi:10.1016/j.ecoenv.2012.05.007.

WATSON, C. F., BAER, K. N., BENSON, W. H. 1989. Dorsal gill incision: A simple method for obtaining blood samples in small fish. Environ. Toxicol.Chem., 8: 457-461. doi:10.1002/ etc. 5620080512 . 